\title{
Development of Asymmetric Multipass Spinning Method for Oblique Cylindrical Shape
}

Yong Xiao ${ }^{1}$, Zhi-Ren Han ${ }^{1,2}$, Zuo-Jun Fan², Zhen Jia ${ }^{2}$

${ }^{1}$ School of Mechanical Engineering, Northwestern Polytechnical University, Shannxi, 710072, China. Email: 525287383@163.com, Hanren888@163.com

${ }^{2}$ Key Lab of Fundamental Science for National Defense of Aeronautical Digital Manufacturing Process, Shenyang Aerospace University, Shenyang, 110136, China. Email: shhybm201@163.com, zjia@alum.imr.ac.cn

In previous studies, an asymmetric product is formed by shear spinning. The wall of the product couldn't be perpendicular to the bottom since the thickness of the wall would reduce to zero in shear spinning. In order to break through the limitation and form an oblique cylindrical shape, an asymmetric multipass spinning method combing conventional spinning with asymmetric spinning was developed in this research. The roller trajectory of asymmetric multipass spinning is deduced. The thickness variation is discussed by analyzing the movement of the roller. The thickness distribution and the surface quality with different experiment parameters are discussed. It indicates that a smaller roller feed rate $f$ and a smaller incremental angle $\Delta \alpha$ can improve the surface quality.

Keywords: Metal spinning, Preforming, Asymmetric Spinning, Roller Pass Design

\section{Acknowledgement}

This work was financially supported by the Natural Science Foundation of Liaoning Province, China (No. 201602558).

\section{References}

[1] O. MUSIC, J.M. ALLWOODA, K. KAWAI. (2010). A review of the mechanics of metal spinning. In: Journal of Materials Processing Technology. Vol. 210, pp. 3-23

[2] CHUNJIAN, S., TIANTIAN, L. (2014). Study on Springback Rule of AZ31B Magnesium Alloy Axisymmetric Part's Warm Single Point Incremental Forming without Mould. In: Manufacturing Technology 14 (4).

[3] CHUNJIAN S., XUETAO W. (2014). Springback Research of V-type Sheet Metal forming based on the Adjustable Drawbead and Variable Blank-holder Force Cooperative Control Technology. In: Manufacturing Technology 14(4).

[4] LUCIE, N., PETR, H., VACLAV, K. (2012). Microstructure Analysis of Titanium alloys after Deformation by means of Asymmetric Incremental Sheet Forming. In: Manufacturing Technology 12(13).

[5] STANISLAW, B., KRZYSZTOF, K., PAWEL, S. (2015). Meaning of Quality Inspection and Control Methods during Manufacturing Process of Metal Sheet Stampings. In: Manufacturing Technology 15(3).

[6] JERZY, J., IVAN, K., MILAN, S., PAWEL, L. (2014). Diagnostics of CNC Machine Tools in Manufacturing Process with Laser Interferometer Technology. In: Manufacturing Technology 14(1).

[7] C.C. WONG, T.A. DEAN, J. LIN. (2003). A review of spinning, shear forming and flow forming processes. In: International Journal of Machine Tools \& Manufacture. No.43, pp. 1419-1435.

[8] AMAnO, T., TAMURA, K., (1984). The study of an Elliptical Cone Spinning by the Trial Equipment. In: Proceedings of the 3rd International Conference of Rotary Metalworking Processes, pp. 213-224.

[9] GAO, X.C., KANG, D.C., MENG, X.F., WU, H.J., (1999). Experimental research on a new technology - ellipse spinning. In: Journal of Materials Processing Technology. 94 (2-3), pp. 197-200.

[10] AWISZUS, B., MEYER, F., (2005). Metal spinning of non-circular hollow parts. In: Bariani, P.F. (Ed.), In: Proceedings of the 8th International Conference on Technology of Plasticity. Verona, Italy, pp. 353-354.

[11] ARAI, H., (2005). Robotic metal spinning - forming non-axisymmetric products using force control. In: Proceedings of the 2005 IEEE International Conference on Robotics and Automation, Barcelona, Spain, pp. 27022707.

[12] SHIMIZU, I. (2010). Asymmetric forming of aluminum sheets by synchronous spinning. In: Journal of Materials Processing Technology. 210 (4), pp. 585-592. 
[13] Q. X. XIA \& Z. Y. LAI \& HUI LONG \& X. Q. CHENG. (2013). A study of the spinning force of hollow parts with triangular cross sections. In: Int J Adv Manuf Technol No. 68, pp. 2461-2470.

[14] ZHIREN H., QIANG X., ZHEN J. AND XINBIAO L. Experimental research on oblique cone die-less shear spinning. In: Proc IMechE Part B: J Engineering Manufacture. pp. 1-8.

[15] Z. JIA, Z. R. HAN, Q. XU, W.F.PENG. (2016). Precision Forming of the Straight Edge of Square Section by Die-Less Spinning. In: Journal of Manufacturing Science and Engineering. 2016, Vol. 138, pp. 1-5.

[16] LIU JIAN-HUA. (2003). Development of Multi-process Conventional Spinning and Research on Roller-Trace. In: Mechanical Science And Technology. Vol.22, No.5, pp. 805-807.

\section{Paper number: M2017113}

Copyright $\left({ }^{\circ}\right.$ 2017. Published by Manufacturing Technology. All rights reserved. 